\title{
NO FINAL VICTORIES: THE INCOMPLETENESS OF EQUITY'S TRIUMPH IN FEDERAL PUBLIC LAW
}

\author{
THOMAS D. Rowe, JR.
}

\section{INTRODUCTION}

If Professor Laycock senses a "segregationist spirit" in some attitudes about keeping equity distinct and intact, ${ }^{1}$ I hear a note of triumphalism about the scope and approaches of equity in the articles for this symposium. At the conference where these papers were first given, I began my comment on the essays of Justice Gummow, ${ }^{2}$ Professor Laycock, ${ }^{3}$ and Chancellor Quillen ${ }^{4}$ with the remark that my role might be that of skunk at Professor DeMott's garden party. Yet to put it that way would exaggerate my point, for I wish to sound a note of partial qualification rather than discord.

Part II discusses prominent areas where the United States Supreme Court has denied equitable relief, demonstrating the limited nature of equity's "triumph" in federal public law. Part III expands the focus of Part II to decisions outside the realm of equity that nonetheless evidence the Court's hostility toward the spirit of equity in the area of federal public law. Finally, Part IV considers the rationales behind the trend away from equity in these federal public law decisions.

II

The Limits of Equity's TriumPH IN FEderal PUblic LAW

Gummow, Laycock, and Quillen describe an impressive triumph of the jurisdiction, procedure, attitudes, and remedies of equity in a range of states and nations and across broad substantive areas. This comment does not differ with what they say, but calls attention to and explores briefly a significant, if partial, exception to this triumph. An outpost that has so far less than fully fallen to the

\footnotetext{
Copyright $\odot 1993$ by Law and Contemporary Problems

* Professor of Law, Duke University.

The title of this comment is borrowed in part from the political autobiography of former Democratic National Chairman Larry O'Brien, LAWRENCE F. O'BRIEN, No FINAL VICTORIES: A LIFE IN POLITICS-FROM JOHN F. KENNEDY TO WATERGATE (1974). For comments on a previous draft, I am grateful to Doug Laycock.

1. Douglas Laycock, The Triumph of Equity, 56 LAW \& CONTEMP. PROBS. 53, 53 (Summer 1993).

2. The Honourable Mr. Justice William Gummow, The Injunction in Aid of Legal Rights-An Australian Perspective, 56 LAw \& CONTEMP. PROBS. 83 (Summer 1993).

3. Laycock, supra note 1.

4. William T. Quillen, Constitutional Equity and the Innovative Tradition, 56 LAW \& CONTEMP.
} PROBS. 29 (Summer 1993). 
triumph of equity is modern U.S. federal public law as addressed in several recent decisions of the Supreme Court. Here, the jurisdiction of federal courts is often construed narrowly and exercised with restraints. Clear rules are often favored over discretion. The irreparable injury rule has not only escaped death but found some invigoration. Reasons of state can justify less-than-full remediation. Even the flexible procedural devices that spread from equity into all of today's merged civil practice can encounter obstacles to their full use.

It may initially seem odd to suggest that a leading, if partial, holdout from the triumph of equity is public law, because one of the most cited articles in modern legal literature is Professor Abram Chayes' description and celebration of an expansive judicial role in federal public law litigation. ${ }^{5}$ To some extent, though, Chayes may have helped flush a target, for many opinions of the Burger and Rehnquist Courts have rejected, or at least cautioned against, key elements of Chayes' vision. ${ }^{6}$ Chayes spoke broadly of the new public law litigation model as involving "a grievance about the operation of public policy" and relief that is "forward looking," "flexible and broadly remedial," rather than being "conceived as compensation for past wrong in a form logically derived from the substantive liability and confined in its impact to the immediate parties."

Contrast Chayes with Justice O'Connor's opinion for the Court in Allen v. Wright, ${ }^{8}$ which denied standing to black parents challenging the alleged laxity of IRS enforcement against tax exemptions for racially discriminatory private schools. ${ }^{9}$ She counseled "against recognizing standing in a case brought, not to enforce specific legal obligations whose violation works a direct harm, but to seek a restructuring of the apparatus established by the Executive Branch to fulfill its legal duties." 10 Such suits "are rarely if ever appropriate for federalcourt adjudication." ${ }^{\prime 11}$ 'Connor offered a second rationale for the Court's conclusion:

5. Abram Chayes, The Role of the Judge in Public Law Litigation, 89 HARV. L. REV. 1281 (1976). The Chayes article ranked eleventh in a survey of modern law review articles most cited in law reviews. See Fred R. Shapiro, The Most-Cited Law Review Articles, 73 CAL. L. REV. 1540, 1550 (1985). By count of citations in Shepard's Law Review Citations since 1979, the Chayes article stood third. See id. at 1554. Chayes is alpha and omega, so to speak, for two of the articles commented upon here: Professor Laycock cites Chayes in his opening footnote, see Laycock, supra note 1, at $53 \mathrm{n} .{ }^{*}$, and Justice Gummow quotes him for his conclusion, see Gummow, supra note 2, at 104 \& n.104. For an assessment of the impact of the Chayes article suggesting that it focused on institutional reform suits already on the wane but helped catalyze thinking about procedural reform, see Richard L. Marcus, Public Law Litigation and Legal Scholarship, 21 U. MICH. J.L. REF. 647 (1988).

6. Chayes himself described and criticized aspects of this limiting trend six years after the Public Law Litigation article. See Abram Chayes, The Supreme Court, 1981 Term-Foreword: Public Law Litigation and the Burger Court, 96 HARV. L. REV. 4 (1982).

7. Chayes, supra note 5, at 1302.

8. 468 U.S. 737 (1984).

9. The plaintiffs did not challenge any particular school's exemption, nor did they allege their children's exclusion from any exempted private school. See id. at 743-46. Rather, they claimed "a direct injury from the mere fact of the challenged Government conduct and ... injury to their children's opportunity to receive a desegregated education." Id. at 746 . The Court took them to be alleging that their rights were "violated by IRS grants of tax-exempt status to some number of unidentified racially discriminatory schools in desegregating districts ...." Id. at 745 n.11.

10. Id. at 761 .

11. Id. at 760 . 


\begin{abstract}
Even if the relief respondents request might have a substantial effect on the desegregation of public schools, [it weighs against finding standing that] whatever deficiencies exist in the opportunities for desegregated education for respondents' children might not be traceable to IRS violations of law-grants of tax exemptions to racially discriminatory schools in respondents' communities. ${ }^{12}$
\end{abstract}

Allen $v$. Wright has special force because, as an Article III standing opinion, ${ }^{13}$ it constitutionalizes some hurdles facing efforts at federal court adjudication after the Chayes model. That decision and the other developments discussed here do not, of course, shut down all such adjudication; just ask some litigants before district judges such as William Wayne Justice. ${ }^{14}$ Still, Allen $v$. Wright erects a threshold barrier that can at least deflect some public law plaintiffs toward suits cast more nearly in the traditional mold that Chayes argued was being transformed. ${ }^{15}$

12. Id. at 753 n.19.

13. See id. at 755-56 (on "constitutional limits on the role of the federal courts" precluding standing to press claims based on "abstract stigmatic injury"); id. at 756-61 (on constitutional problem with finding standing for Allen $v$. Wright plaintiffs to litigate the non-abstract injuries that they did allege because those injuries were not "fairly traceable" to the government action).

14. See, e.g., Young v. Pierce, 685 F. Supp. 975 (E.D. Tex. 1988) (Justice, C.J.) (ordering federal Department of Housing and Urban Development to implement affirmative action tenant-assignment program in numerous low-rent housing projects, and vesting in special master power to investigate Department's activities and monitor its compliance); Ruiz v. McCotter, 661 F. Supp. 112 (S.D. Tex. 1986) (Justice, C.J.) (enforcing previously entered state prison reform orders with civil contempt findings and order). Judge Justice, of the Eastern District of Texas, had been assigned to preside in the consolidated statewide Ruiz prison conditions litigation after it was transferred to the Southern District. See Ruiz v. Estelle, 503 F. Supp. 1265, 1275-76 (S.D. Tex. 1980), aff'd in part and rev'd in part, 679 F.2d 1115 (5th Cir.), opinion amended in part and vacated in part, 688 F.2d 266 (5th Cir. 1982). See generally William Wayne Justice, The Two Faces of Judicial Activism, 61 GEO. WASH. L. REV. 1 (1992) (distinguishing "jurisprudential activism," overrulling precedents or finding legislation unconstitutional based on values determined by judges, from "remedial activism" of expansive remedies for demonstrated constitutional violations, and defending his use of the latter variety).

15. See Chayes, supra note 5 , at $1282-83$ (listing features of traditional conception of civil adjudication: bipolar lawsuit; retrospective; interdependent right and remedy; lawsuit as self-contained episode; and process party-initiated and party-controlled).

Writing in 1982, Chayes questioned the effect of the Court's decisions narrowing standing: "[T]he great standing expansion of the 1960's remains relatively untouched; in the vast majority of public law cases, it has been possible to turn up a plaintiff who has suffered the requisite injury in fact." Chayes, supra note 6 , at 23 (footnote omitted). That may have been and may remain true to a considerable extent, but Chayes wrote before the two major standing limitation decisions of the $1980 \mathrm{~s}$, Allen $v$. Wright and City of Los Angeles v. Lyons, 461 U.S. 95 (1983) (denying constitutional standing to seek injunctive relief to victim of police chokehold on ground that likelihood of repetition as to him posed insufficient threat to establish required injury). After a period of relative quiescence in the late 1980s, the Court has again taken a narrow view of constitutional standing in Lujan v. Defenders of Wildlife, $112 \mathrm{~S}$. Ct. 2130 (1992) (environmental and animal rights organizations lack standing to challenge Secretary of Interior's narrowing of regulation concerning other federal agencies' obligation to consult with him under Endangered Species Act about projects within foreign countries, even though some of organizations' members alleged that they had visited, and planned to visit again, foreign sites that could be affected by regulation change).

Allen $v$. Wright and Defenders of Wildlife could be especially significant in undermining Chayes' 1982 argument because they dealt in part not with the injury requirement upon which he focused but on the causation aspect of constitutional standing requisites. See Allen $v$. Wright, 468 U.S. at 753 \& n.19, 756-61; Defenders of Wildlife, 112 S. Ct. at 2140-42 (plurality opinion). Defenders of Wildlife also 
Even when such plaintiffs surmount standing hurdles, an equitable remedy may not be easy to get. In City of Los Angeles v. Lyons, ${ }^{16}$ the Supreme Court majority took the extraordinary step of discussing and rejecting the availability of federal equitable relief against allegedly unconstitutional police chokeholds after it had ruled against federal jurisdiction on constitutional standing grounds. ${ }^{17}$ Even with no state adjudications pending, the Court said that not only equity but principles of comity and federalism "should inform the judgment of federal courts when asked to oversee state law enforcement authorities. In exercising their equitable powers federal courts must recognize ' $[\mathrm{t}] \mathrm{he}$ special delicacy of the adjustment to be preserved between federal equitable power and State administration of its own law." 18 Instead of a federal suit with a possible injunctive remedy, chokehold victim Lyons could sue for damages, rely on possible criminal prosecution of Los Angeles police officers, or hope that the state courts' standing and remedial requirements were not so demanding. ${ }^{19}$

The most striking limit on federal equitable relief, and the sharpest contrast with the developments discussed in the papers commented on, is the heightening of the irreparable injury requirement in the Younger v. Harris ${ }^{20}$ line of cases. The Younger doctrine governs the availability of federal injunctive and declaratory relief against many pending state criminal and civil proceedings, and some state administrative adjudications.

In his last Term, Justice Hugo Black wrote for the Court in the Younger opinion that even if the federal Anti-Injunction Statute ${ }^{21}$ poses no bar, ${ }^{22}$ a federal court is not to enjoin a pending state prosecution on a showing of ordinary irreparable harm, but must find irreparable injury "'both great and immediate." ${ }^{23}$ Such showings will be rare, requiring "bad faith, harassment, or

imposed constitutional limits on Congress' power to confer upon private parties standing to enforce Executive obligations to observe procedures required by law. See id. at 2142-46 (majority opinion).

16. 461 U.S. 95 (1983).

17. See id. at 101-10 (discussing reasons for finding no Article III case or controversy in plaintiff's count seeking injunctive relief against police chokehold policy, before turning to availability of injunctive remedy "if it be assumed that [plaintiff's] pending damages suit affords him Art. III standing to seek an injunction ...," id. at 111).

18. Id. at 112 (quoting Stefanelli v. Minard, 342 U.S. 117, 120 (1951)).

19. See Lyons, 461 U.S. at 113.

20. 401 U.S. 37 (1971).

21. 28 U.S.C. $\& 2283$ (1988) ("A court of the United States may not grant an injunction to stay proceedings in a State court except as expressly authorized by Act of Congress, or where necessary in aid of its jurisdiction, or to protect or effectuate its judgments.").

22. Cf. Younger, 401 U.S. at 54 ("Because our holding rests on the absence of the factors necessary under equitable principles to justify federal intervention, we have no occasion to consider whether [the Anti-Injunction Statute] would in and of itself be controlling under the circumstances of this case."). The Court subsequently held in Mitchum v. Foster that 42 U.S.C. $\$ 1983$, the umbrella statute generally authorizing actions for alleged state deprivations of federal rights, qualifies as an "expressly authorized" exception to $\S 2283$. 407 U.S. $225,242-43$ (1972). Section 1983 claimants seeking federal court anticipatory relief against pending state proceedings, however, must still satisfy Younger's requirements. See ERWIN CHEMERINSKY, FEDERAL JURISDICTION § 11.2.2, at 561 (1989) ("Section 1983 constitutes an exception to the Anti-Injunction Act, but not to the Younger doctrine.").

23. Younger, 401 U.S. at 46 (quoting Fenner v. Boykin, 271 U.S. 240, 243 (1926)). 
[some] other unusual circumstance that would call for equitable relief."24 By contrast, as Justice Gummow points out, in Australia's (less prominent) public law litigation, the High Court seems to have declined to require an extraordinary showing-of a need to prevent "grave injustice"-as a prerequisite to an interim injunction. ${ }^{25}$ And Professor Laycock's prodigious research supports the conclusion that equitable remedies have generally become "ordinary, not extraordinary." ${ }^{26}$ Yet as he has previously argued, certain applications of the Younger limit-especially to persons who want to engage in a continuing course of conduct and are prosecuted for past acts-may mean that no adequate relief is available. ${ }^{27}$ Such a result is contrary to the insistence on full adequacy that pervades all the fields surveyed in this symposium by Gummow, Laycock, and Quillen.

One should not come away with the impression that federal equitable relief has lost most of its bite, even in public law cases. The areas just discussed are especially prominent and sensitive; they should not obscure what Laycock describes as the "routine" use of injunctions in such significant public law areas as environmental, civil rights, and constitutional litigation. ${ }^{28}$ Even in cases posing the most acute of federal-state tensions, the picture is mixed. As recently as 1990, a bare majority of the Supreme Court upheld federal judicial power to order a local government to levy taxes to fulfill an obligation imposed by federal law, no matter if such taxes would exceed the authority granted the locality by state law. ${ }^{29}$ Since-retired Justices Brennan, White, and Marshall, however, were needed for the majority, and such expansive views of federal courts' remedial authority might get as warm a welcome from the current Court as has the Chayes model. ${ }^{30}$

24. Younger, 401 U.S. at 54 . On the rarity with which relief can issue when Younger's extraordinary-showing requirements apply, see, e.g., CHEMERINSKY, supra note $22, \S 13.4$.

25. See Gummow, supra note 2, at 88 (discussing Castlemaine Tooheys Ltd. v. South Australia, [1986] 161 C.L.R. 148 (Austl.)). The Ontario standard apparently rejected in Castlemaine Tooheys placed a heavy burden indeed on those challenging the constitutional validity of laws and seeking interim injunctive relief, a burden stated in terms strikingly similar to those used in Younger: "[I]n exceptional circumstances this court [may grant] an interim injunction to prevent grave injustice, but that will be rare indeed." Morgentaler v. Ackroyd, [1983] 42 O.R.2d 659, 668 (High Ct.).

26. Laycock, supra note 1 , at 54.

27. See generally Douglas Laycock, Federal Interference with State Prosecutions: The Need for Prospective Relief, 1977 SUP. CT. REV. 193.

28. Laycock, supra note 1, at 57.

29. Missouri v. Jenkins, 495 U.S. 33, 55-58 (1990).

30. Indeed, earlier in the same Term in which the Court decided Jenkins, a switch of one vote (that of Justice White) had made a 5-4 majority the other way in a similar case. The Court struck down, as an abuse of equitable discretion, the imposition of contempt sanctions against city council members for failing to adopt an ordinance the city had agreed to enact pursuant to a federal court remedial order in a housing discrimination case, and which the court had ordered enacted after delays by the city in implementing the agreement. See Spallone v. United States, 493 U.S. 265 (1990). For commentary discussing both Jenkins and Spallone, see The Supreme Court, 1989 Term-Leading Cases, 104 HARV. L. REV. 129, 296-308 (1990). 
III

\section{BEYOND EQUITY: ThE COURT AND THE SPIRIT OF EQUITY IN OTHER AREAS}

The fields just discussed perhaps best illustrate the recent tendency of the Supreme Court to limit the availability and use of broad federal equitable authority. Three other examples of developments in decisions outside the realm of equity offer further contrasts with the spirit documented in the Gummow, Laycock, and Quillen articles. These are: first, the limits on implied private rights of action for federal constitutional violations by federal officials under cases after Bivens v. Six Unknown Named Agents of Federal Bureau of Narcot$i c s ;{ }^{31}$ second, occasional manifestations of highly positivist or narrow approaches to construction of the Constitution, statutes, treaties, and rules; and third, procedural rulings that raise questions about how fully equity has conquered common law, specifically cases on heightened pleading requirements and decisions affecting the use of joinder devices derived from, but no longer limited to, equity.

Equity may "delight[] to do justice and not by halves," 32 and it may "not suffer[] a wrong to be without a remedy." ${ }^{33}$ Following the same spirit in cases dealing with damages, the Court had shown itself willing to allow damage claims for constitutional deprivations by federal officials when Congress had afforded no remedy. ${ }^{34}$ However, in the last several years the Court has refused to extend that willingness to situations in which Congress has afforded an incomplete remedy. It is now clear that if Congress provides even a limited remedy for a constitutional deprivation by federal officials, whether or not it focused on cases involving harm beyond the remedy limits, and whether or not it explicitly said that a claimant can get no more than the statutory remedy provides, the statutory provision will ordinarily set the limit even when it gives less-than-full remediation. ${ }^{35}$ The Supreme Court's deference to Congress when

31. 403 U.S. 388 (1971).

32. Laycock, supra note 1, at 65 ; see also Quillen, supra note 4, at 50.

33. Quillen, supra note 4 , at 50.

34. See Davis v. Passman, 442 U.S. 228 (1979) (allowing Fifth Amendment damage claim for gender discrimination against member of Congress); Bivens, 403 U.S. 388 (1971) (allowing Fourth Amendment damage claim against federal narcotics agents).

35. See Schweiker v. Chilicky, 487 U.S. 412, 421-22 (1988) ("The absence of statutory relief for a constitutional violation ... does not imply ... that courts should award money damages against the officers responsible for the violation."). On the facts of Chilicky, the majority "agree[d] that suffering months of delay in receiving the [Social Security disability benefit] income on which one has depended for the very necessities of life cannot be fully remedied by the "belated restoration of back benefits," id. at 428 , and conceded that "[ $t$ ]he trauma to respondents, and thousands of others like them, must surely have gone beyond what anyone of normal sensibilities would wish to see imposed on innocent disabled citizens," id. at 428-29. Still, it rejected "the notion that statutory violations caused by unconstitutional conduct necessarily require remedies in addition to the remedies provided generally for such statutory violations," $i d$. at 427 , and stated that "the presence of alleged unconstitutional conduct that is not separately remedied under the statutory scheme [does not] imply that the statute has provided 'no remedy' for the constitutional wrong at issue," id. at 427-28 (emphasis in original). 
a statutory remedy provides less-than-full relief for a constitutional violation contrasts with the rule in Delaware that the Delaware General Assembly cannot constitutionally curtail the general equity jurisdiction of the Court of Chancery without providing an adequate remedy at law. ${ }^{36}$

Underlying decisions like those that limit Bivens remedies against federal government officials may be a certain statism on the part of some Justices. ${ }^{37}$ At times it seems that while claimants against government wrongs like those in Schweiker $v$. Chilicky ${ }^{38}$ get only what the law specifically allows, ${ }^{39}$ the government may get against an individual everything that the law does not expressly forbid. ${ }^{40}$ Whatever the tilt, in some modern Supreme Court opinions there appears a highly positivist attitude ${ }^{41}$ that is far removed from Delaware's equi-

A subsequent decision of the District of Columbia Circuit illustrates the confining force of Chilicky. Two panels had issued conflicting opinions on parallel Bivens claims before Chilicky, and the court granted rehearing en banc in both cases. After Chilicky, the often fiercely divided circuit was able to issue a unanimous opinion ruling against the Bivens claims. The D.C. Circuit viewed "the Chilicky Court [as having] made clear that it is the comprehensiveness of the statutory scheme involved, not the 'adequacy' of specific remedies extended thereunder, that counsels judicial abstention." Spagnola v. Mathis, 859 F.2d 223, 227 (D.C. Cir. 1988) (en banc) (per curiam). Under Chilicky, "courts must withhold their power to fashion damages remedies when Congress has put in place a comprehensive system to administer public rights, has 'not inadvertently' omitted damages remedies for certain claimants, and has not plainly expressed an intention that the courts preserve Bivens remedies." Id. at 228.

36. See Quillen, supra note 4, at 38-40. Further, even if the General Assembly provides a "full, adequate, and complete remedy at law," concurrent equitable jurisdiction survives "unless the General Assembly expressly states or necessarily implies that the legal remedy is exclusive." Id. at 37 .

37. See Guido Calabresi, The Supreme Court, 1990 Term-Foreword: Antidiscrimination and Constitutional Accountability (What the Bork-Brennan Debate Ignores), 105 HARV. L. REv. 80, 140 (1991) (Rehnquist Court's failure to use intermediate approaches, or to protect asserted rights allegedly because to do so "would be anti-majoritarian," "reflects either woeful ignorance or a willful 'statist' desire to negate the alleged rights regardless of their true majoritarian support").

38. See supra note 35 and accompanying text.

39. Chilicky, involving a possible claim against an individual government official, raised no problems of sovereign immunity. When states' Eleventh Amendment immunity against individual damage suits in federal court has been at issue, the Court has recently stiffened-if that be possible-the already extraordinary showings required to find congressional abrogation of state sovereign immunity. "Lest [a previous decision] be thought to contain ambiguity, we reaffirm today that . . . evidence of Congressional intent must be both unequivocal and textual." Dellmuth v. Muth, 491 U.S. 223, 230 (1989). "In particular," the Dellmuth Court rejected the relevance of legislative history to such findings, requiring that Congress' intention be "“unmistakably clear in the language of the statute." Id. (quoting Atascadero State Hospital v. Scanlon, 473 U.S. 234, 242 (1985)).

40. See United States v. Alvarez-Machain, 112 S. Ct. 2188 (1992) (rejecting claim that extradition treaty with Mexico should be construed to prohibit suspect's extrajudicial abduction, for which U.S. authorities were responsible, from Mexican territory for trial in United States, even though Mexico protested and abduction violated international law); $c f$. William D. Popkin, An "Internal" Critique of Justice Scalia's Theory of Statutory Interpretation, 76 MINN. L. REV. 1133, 1138 \& n.36 (1992) (noting contrast between positions in Justice Scalia's opinion for the Court in Boyle v. United Technologies Corp., 487 U.S. 500 (1988) (allowing federal common law defense to state tort claim for federal military contractors), and his concurrence in the judgment in Thompson v. Thompson, 484 U.S. 174, 192 (1988) (suggesting abandonment of judicial recognition of implied private statutory rights of action)).

41. See, e.g., Arnett v. Kennedy, 416 U.S. 134, 153-54 (1974) (plurality opinion) (Rehnquist, J.) ("where the grant of a substantive right is inextricably intertwined with the limitations on the procedures which are to be employed in determining that right, a [procedural due process claimant] must take the bitter with the sweet"). The Court has since rejected the "bitter with the sweet" approach of the Arnett plurality, see, e.g., Cleveland Bd. of Educ. v. Loudermill, 470 U.S. 532, 541 (1985); but a similar attitude resurfaces and at times prevails in cases like Alvarez-Machain, 112 S. Ct. 2188. 
table concept that "inequitable action does not become permissible simply because it is legally possible." 42

A kindred rigor of construction appears in some areas of procedure affecting federal public law actions. Professor Laycock, drawing on the work of Professor Stephen Subrin, ${ }^{43}$ counts among the triumphs of equity over common law "the rejection of technical pleading rules in favor of simple, straightforward pleading, the extreme development of which was captured in the phrase 'notice pleading." "44 Yet in the important standing case of Warth v. Seldin, ${ }^{45}$ Justice Powell's Court opinion referred repeatedly to the need for plaintiffs to "allege facts" to show aspects of standing, ${ }^{46}$ and parsed the complaint to point out fine omissions of the sort ordinarily dealt with in modern practice well after the pleading stage. ${ }^{47}$ With what seems like ample justification, Justice Brennan's dissent chastised the majority opinion for its "overtones of outmoded notions of pleading" 48 and for "reverting to the form of fact pleading long abjured in the federal courts." 49

A final set of examples of the restrictive tendencies described comes from Supreme Court decisions affecting the use of party joinder devices, whose modern breadth Laycock presents as another aspect of equity procedure's triumph..$^{50}$ Since at least the early 1970 s, the Court has ruled several times against ancillary jurisdiction involving some of the more aggressive, yet generally permissible, forms of party joinder. The decisions effecting these restrictions cut across public and private law litigation alike, although they often happen to have evolved in cases with public law overtones.

The clearest recent instance of this approach is Justice Scalia's opinion for the five-Justice majority in Finley $v$. United States. ${ }^{51}$ Although joining as co-defendants alleged tortfeasors who may be jointly, severally, or alternatively

42. Schnell v. Chris-Craft Indus., Inc., 285 A.2d 437, 439 (Del. 1971), quoted in Quillen, supra note 4, at 49. Schnell is alive and well in Delaware. After quoting the statement reproduced in text and describing it as the "crux of Schnell," the Supreme Court of Delaware recently observed: "Schnell's broad holding spawned an entirely new line of Court of Chancery decisions." Stroud v. Grace, 606 A.2d 75, 91 (Del. 1992) (citations omitted).

43. Stephen N. Subrin, How Equity Conquered Common Law: The Federal Rules of Civil Procedure in Historical Perspective, 135 U. PA. L. REV. 909 (1987).

44. Laycock, supra note 1, at 65 .

45. 422 U.S. 490 (1975).

46. See, e.g., id. at $504,516$.

47. See id. at 504-18 passim. In the recent case of Lujan v. Defenders of Wildlife, $112 \mathrm{~S}$. Ct. 2130 (1992), Justice Scalia's majority opinion, although holding against standing, may signal a turn back toward less rigorous pleading attitudes. His opinion says that at "the pleading stage, general factual allegations of injury resulting from the defendant's conduct may suffice ..."Id. at 2137 . He goes on to contrast the greater specificity required in response to a summary judgment motion, or in the support necessary at trial if relevant facts remain controverted. See id.

48. Warth, 422 U.S. at 520 (Brennan, J., dissenting).

49. Id. at 528.

50. See Laycock, supra note 1, at 65 ("Equity took the ... position ... that all interested parties should be joined so that complete justice could be done in every case. . . . Our modern . . . joinder rules obviously build on the equity model[.]").

51. 490 U.S. 545 (1989). 
liable is permissible party joinder under Federal Rule of Civil Procedure 20(a), ${ }^{52}$ Finley forbade "pendent party" jurisdiction over a Federal Tort Claims Act ("FTCA") plaintiff's state law claim against a nondiverse private defendant. The impact was especially unfortunate as federal jurisdiction over FTCA claims against the United States is exclusive ${ }^{53}$ an FTCA plaintiff thus had to file separate federal and state court actions, or to forgo either the claim against the United States or that against a private defendant who could not be sued in federal court. The Scalia opinion made its premise, and its attitude toward statutory construction at least in this sub-area, clear: "[W]ith respect to the addition of parties, as opposed to the addition of only claims, we will not assume that the full constitutional power has been congressionally authorized, and will not read jurisdictional statutes broadly." 54 The opinion issued a virtual invitation to Congress to legislate if it did not like the result. ${ }^{55}$ The consequences of the Finley ruling were severe enough that Congress acted promptly, overruling Finley and largely taking the leading role in the area that is now called "supplemental jurisdiction" away from the federal courts. ${ }^{56}$

Finley drew on a line of cases including Zahn v. International Paper Co. ${ }^{57}$ In Zahn, the Court completely ignored ancillary jurisdiction arguments made at length by the dissent, ${ }^{58}$ and ruled against federal jurisdiction over unnamed plaintiff class members in a Rule 23(b)(3) diversity class action ${ }^{59}$ if their separate claims did not independently satisfy the amount in controversy requirement, even though the named representatives' claims were large enough. For cases part of which can or must be in federal court, the effect of Zahn is somewhat like that of Finley. The Zahn rule refuses to let related claims not within original federal jurisdiction tag along. Plaintiffs must either proceed in both state and federal court, forgo one or another set of claims, or-if none of the claims is within exclusive federal jurisdiction-abandon the federal forum afforded by Congress and seek a single adjudication in state court.

Zahn, in turn, is one in a series of leading cases in which the Court clipped the wings of the federal class action, a child of equity. Some of the other

52. FED. R. CIV. P. 20(a):

... . All persons ... may be joined in one action as defendants if there is asserted against them jointly, severally, or in the alternative, any right to relief in respect of or arising out of the same transaction, occurrence, or series of occurrences and if any question of law or fact common to all defendants will arise in the action. ...

53. 28 U.S.C. \& 1346 (b) (1988).

54. Finley, 490 U.S. at 549.

55. See id. at 556 ("Whatever we say regarding the scope of jurisdiction conferred by a particular statute can of course be changed by Congress.").

56. See 28 U.S.C. $\$ 1367$ (Supp. III 1991).

57. 414 U.S. 291 (1973).

58. See id. at 303-12 (Brennan, J., dissenting).

59. Federal Rule of Civil Procedure 23(b)(3) permits class action treatment if Rule 23(a) prerequisites are met and if "the court finds that the questions of law or fact common to the members of the class predominate over any questions affecting only individual members, and that a class action is superior to other available methods for the fair and efficient adjudication of the controversy." 
important restrictive decisions, though, seem more defensible than Zahn. ${ }^{60}$ Further, by no means have all the Court's class action rulings been restrictive. ${ }^{61}$ Still, the cases do show that the triumph of equity ${ }^{62}$ has been only partial, with some especially significant limits, in areas that involve or at least bear on federal public law.

\section{IV}

\section{Rationales for the NarRowing Trend in Public LaW Decisions}

If it is worthwhile in itself to point out the differences between equity's general triumph in many other respects and the limits on its conquest in modern federal public law, it is also important to consider the sources and significance of the contrast. Three main themes appear on the surface of the decisions: first, concern for interbranch separation of powers and limits on the role of the federal judiciary; second, deference to state interests in the name of federalism; and third, the influence of formalist "plain meaning" approaches to statutory construction. Separation of powers, federalism, and plain meaning construction are large topics on which much has been and could be written; this short comment is not the place for extended further discussion. This section tries only to address the roots of these concerns, to illustrate some reliance on these themes in the cases, and to offer observations on the applications discussed above.

At the moment, strong emphasis on separation of powers, federalism, and plain meaning tends to be associated with conservative judicial and political thinking. ${ }^{63}$ The ascendancy of these attitudes can be no surprise since nearly

60. See Eisen v. Carlisle \& Jacquelin, 417 U.S. 156 (1974) (relying on Rule 23(c)(2)'s requirement for (b)(3) class actions of "individual notice to all members who can be identified through reasonable effort" to forbid random selection of sample of very large class to receive notice); Snyder v. Harris, 394 U.S. 332 (1969) (forbidding aggregation of separate and distinct claims to satisfy amount in controversy requirement when no named or unnamed class member's individual claim allegedly did so). For criticism of Snyder, Zahn, Eisen, and other restrictive Supreme Court class action decisions, see Chayes, supra note 6 , at $28-39$.

61. See, e.g., Gulf Oil Co. v. Bernard, 452 U.S. 89 (1981) (striking down order restricting communications by counsel for the plaintiff class's representatives to prospective class members); United States Parole Comm'n v. Geraghty, 445 U.S. 388 (1980) (under class action exception to mootness doctrine, appellate correction of erroneous denial of class certification relates back to date of original denial); County of Riverside v. McLaughlin, 111 S. Ct. 1661 (1991) (reaffirming Geraghty and applying class action exception to case in which class representatives' claims had become moot before trial court could rule on class certification).

62. The term "equity" is used loosely here to include matters not unique to but characteristic of equity, such as emphasis on full remediation and broad joinder. By relying on the term for convenience, I mean to convey no disagreement with Professor Laycock's substantive position that (jury trial issues aside) arguments and decisions about the content of legal rules should turn on functional considerations and not the historic law-equity distinction. See Laycock, supra note 1, at 56, 73-78.

63. The qualifier "at the moment" is used because purported allegiances to somewhat abstract concerns, such as federalism, tend to shift on the political spectrum with changes over time in substantive issues and control over different loci of power in United States government. On the historical contingency of such leanings, see Richard $\mathrm{H}$. Fallon, Jr., The Ideologies of Federal Courts Law, 74 VA. L. REV. 1141, 1146-47 n.17 (1988) (noting liberals' emphasis on states' rights themes during Lochner era of progressive state legislatures and conservative federal courts, and earlier in opposition to pro- 
all Supreme Court nominations for the past quarter century have partly been animated by reaction against the perceived excesses of, paradigmatically, the Warren Court. ${ }^{64}$ Sometimes it is at least plausible to suspect covert substantive leanings at work behind the superficially neutral rhetoric of the current Court's opinions. ${ }^{65}$ Yet I see insufficient reason to doubt that the often fully overt views on separation of powers, federalism, and plain meaning interpretation are anything but genuine and influential, if not always controlling or treated with full consistency. ${ }^{66}$

Allen $v$. Wright, discussed above, ${ }^{67}$ exemplifies reliance on separation of powers in one of the cases showing the incomplete triumph of equity in federal public law. The Court there asserted (with a questionable, unqualified sweep) that "the law of Art. III standing is built on a single basic idea-the idea of separation of powers." 68 Although Justice O'Connor's effort at supplying an animating concern to help lower courts in construing and applying standing requirements seems oversimplified at best, it does reflect the majority's apparent sense that resort to the courts, rather than the political process, should generally be denied to ideological plaintiffs with dubious direct injury or attenuated links to the challenged government conduct. In addition, even though the separation of powers emphasis in standing was not so crystallized at the time of Warth $v$. Seldin, the hostile parsing of the pleadings there ${ }^{69}$ may be understandable if seen as reflecting judicial caution at starting down the path toward possible constitutional invalidations of political decisions without a clear showing of a

slaveholder Supreme Court decisions).

64. For a thoughtful critique of a broad judicial role in the making and enforcement of public policy, see Donald L. Horowitz, THE COURTS AND SOCIAL POLICY (1977).

65. See, e.g., Gene R. Nichol, Jr., Abusing Standing: A Comment on Allen v. Wright, 133 U. PA. L. REV. 635, 659 (1985) ("One could perhaps be forgiven for confusing standing's agenda with that of the New Right."); see supra notes 37-40 and accompanying text.

66. For a critique of the consistency of conservative judges' reasoning in standing and Eleventh Amendment cases, see Glenn H. Reynolds, Penumbral Reasoning on the Right, 140 U. PA. L. REV. 1333 (1992) (arguing that separation of powers and federalist reasoning used to support narrow standing and broad Eleventh Amendment decisions shows same "penumbral" approaches that conservatives criticize in such decisions as Griswold v. Connecticut, 381 U.S. 479 (1965), and that such departures from textualism are more justified to protect individual rights than in other areas).

67. See supra text accompanying notes 8-15.

68. Allen v. Wright, 468 U.S. 737, 752 (1984). But see Flast v. Cohen, 392 U.S. 83, 100-01 (1968):

The question whether a particular person is a proper party to maintain the action does not, by its own force, raise separation of powers problems related to improper judicial interference in areas committed to other branches of the Federal Government. ... Thus, in terms of Article III limitations on federal court jurisdiction, the question of standing is related only to whether the dispute sought to be adjudicated is presented in an adversary context and in a form historically viewed as capable of judicial resolution.

If standing rests exclusively on separation of powers, as the Court seems to say in Allen v. Wright, it is hard to see why a standing problem should ever exist in challenges to action by state or local, rather than federal, governments. Moreover, reliance on separation of powers to say that a matter is for the political branches to resolve risks turning traditionally party-focused standing into a subject matter-based denial of judicial competence, historically the office of the political question doctrine. See Allen v. Wright, 468 U.S. at 792 (Stevens, J., dissenting) (footnote omitted) (urging that the Court "straightforwardly [consider] the justiciability of the issues [raised], rather than using those issues to obfuscate standing analysis").

69. See supra text accompanying notes $45-49$. 
concrete dispute. The result, though, has been a technical and notably manipulable doctrine that dubiously favors challenges by the targets of regulation over those by intended beneficiaries. ${ }^{70}$ The Court's approach also diverts what ought to be a direct, if not always simple, determination of who should be entitled to seek enforcement of an asserted legal duty toward metaphysical inquiries into "injury in fact," "traceability," and "redressability."11

The strongest other illustration of the role of separation of powers emphases in drawing the Court away from a position consistent with the triumph of equity comes from recent decisions in the Bivens line of cases. These holdings treat damage remedies but implicate the (not uniquely, to be sure) equitable emphasis on full remediation. In the now leading case of Schweiker v. Chilicky, ${ }^{72}$ which denied further Bivens remedies for federal officials' constitutional violations when Congress has provided partial relief without expressing itself either for or against a supplemental Bivens remedy, the majority's explanation sounds strongly in deference to relative legislative competence and responsibility: "When the design of a Government program suggests that Congress has provided what it considers adequate remedial mechanisms for constitutional violations that may occur in the course of its administration, we have not created additional Bivens remedies."73

The Bivens issue arises, of course, because Congress has not said whether it considers the statutory remedial mechanisms adequate. The presumption with which the courts approach that determination, when serious wrongs can remain unrelieved if congressionally provided remedies are exclusive, thus becomes vital. For the dissenters, when Congress had "never mentioned, let alone debated, the desirability of providing a statutory remedy" beyond back benefits for harms suffered by disability claimants affected by constitutionally wrongful cutoffs, it was "inconceivable that Congress meant by mere silence to bar all redress for such injuries." 74

The majority's response joins issue on the question of approach, sounding again the separation of powers theme of the relative roles of the different branches: "Whether or not we believe that its response was the best response, Congress is the body charged with making the inevitable compromises required in the design of a massive and complex welfare benefits program." Why this legislative responsibility justifies a presumption against - rather than for-full remediation, when Congress could adapt to either approach, is defended in concrete terms only by a reference to recruitment difficulties stemming from the "prospect of personal liability for official acts."76 That justification is, however,

70. See Cass R. Sunstein, Standing and the Privatization of Public Law, 88 ColUM. L. REV. 1432, 1459-60 (1988).

71. See generally William A. Fletcher, The Structure of Standing, 98 YALE L.J. 221 (1988).

72. 487 U.S. 412 (1988).

73. Id. at 423 .

74. Id. at $431-32$ (Brennan, J., dissenting).

75. Id. at 429 (opinion of the Court).

76. Id. at 425 . 
a form of double counting because approval of Bivens actions would still leave officials with the full panoply of immunity defenses, which rest partly on the same concern for the effect of officials' personal liability on recruitment of officials. $^{77}$

Turning from separation of powers to federalism emphases, the Younger $v$. Harris line of cases is often referred to by the label "Our Federalism," an infelicitous phrase used by Justice Black. ${ }^{78}$ The equitable relief discussion in City of Los Angeles $v$. Lyons ${ }^{79}$ also brought the federalism theme amply to the surface. The stress on considering intrusions upon state autonomy in deciding on the availability of federal equitable relief reflects a degree of states'-rightism seen in some other areas, such as Eleventh Amendment jurisprudence. ${ }^{80}$ And as with individual officials' immunities when they are successfully invoked in civil rights damage actions, Younger's federalism-based constraints on federal equity can deny full relief for what is or may be a deprivation of a federal right.

The question becomes how strong the justifications are for such denials. With individual officials' immunities ${ }^{81}$ the functional concerns for official performance and recruitment, and the fairness of liability if officials must pay for deprivations they could not reasonably have been expected to know were unlawful, are apparent and support at least the core of immunity doctrine ${ }^{82}$ if not some of its extensions. ${ }^{83}$ Federalism is a more abstract justification, and it is hard to identify concrete harms if federal courts with congressionally authorized jurisdiction grant otherwise unavailable full injunctive relief against irreparable harm from deprivations of federal rights. ${ }^{84}$

The third theme, a degree of strict-constructionist formalism, may help account for some of the other limits noted on the triumph of the spirit of equity. Professor Laycock sensitively notes both the prevailing acceptance of judicial discretion along with the poor light in which "formalism" is viewed, ${ }^{85}$ and the

77. See, e.g., CHEMERINSKY, supra note $22, \S 8.6 .1$, at 403 .

78. See Younger v. Harris, 401 U.S. 37, 44 (1971).

79. 461 U.S. 95 (1983); see supra text accompanying note 18.

80. See supra note 39 . The Court has recently extended its Eleventh Amendment "plain statement" approach into the construction of federal statutes that might raise Tenth Amendment issues. See Gregory v. Ashcroft, $111 \mathrm{~S}$. Ct. 2395, 2404 (1991) ("We will not read the [Age Discrimination in Employment Act] to cover state judges unless Congress has made it clear that judges are included. ... [I]t must be plain to anyone reading the Act that it covers judges.") (emphasis in original); id. at 23992403 (discussing federalism and Tenth Amendment concerns, "plain statement" rule of Eleventh Amendment cases, and its utility in avoiding possible constitutional problems).

81. These immunities, although available to state and local officials, are not federalist in their grounding, as parallel immunities govern in actions against federal officials. See Harlow v. Fitzgerald, 457 U.S. 800, 809 (1982); Butz v. Economou, 438 U.S. 478, 496-504 (1978).

82. See CHEMERINSKY, supra note $22, \$ 8.6 .1$, at 403.

83. See id. \& 8.6.3, at $416-19$.

84. See generally Laycock, supra note 27 , at 231 :

Rigid insistence that only great and immediate injury to the federal plaintiff offsets the state's interests ignores the extent to which the inadequacy of the state remedy directly eliminates some of the state's interests from the balance. The desire to avoid negative reflection on the state courts simply drops out of the equation when the federal intervention is to grant relief unavailable there.

85. Laycock, supra note 1 , at 75 . 
virtues of and defenses for some degrees and applications of formalism. ${ }^{86}$ Wherever that debate had stood in recent times, the Supreme Court today is often pushing this ever-oscillating pendulum ${ }^{87}$ toward a greater degree of formalism.

A prime expression of this spirit comes in Justice Scalia's lecture, The Rule of Law as a Law of Rules. ${ }^{88} \mathrm{He}$ cites some common advantages of "establishing as soon as possible a clear, general principle of decision," ${ }^{19}$ including predictability ${ }^{90}$ and avoidance of judicial arbitrariness. ${ }^{91}$ He also points to the limits on the Supreme Court's ability to superintend areas of the law. ${ }^{92}$ Scalia acknowledges the inevitability of more discretionary modes of decision: "We will have totality of the circumstances tests and balancing modes of analysis with us forever-and for my sins, I will probably write some of the opinions that use them." 93 Yet it is little if any exaggeration to say that he strives to minimize the scope for judicial discretion. ${ }^{94}$ He does so not only for the reasons just mentioned but also because his views on the separation of powers lead him to seek to avoid judicial lawmaking. ${ }^{95}$

Although Justice Scalia does qualify his position and is only one voice on the Court, his influence shows in such opinions as Finley. ${ }^{96}$ His position seems in harmony with the positivist strains ${ }^{97}$ that can run counter to the spirit of equity - and, for that matter, to the policy-based and flexible tradition of adjudication in the substantive common law. ${ }^{98}$ It is also consistent with recent decisions such as the formalistic (albeit defensible) invalidation of the legislative veto in I.N.S. v. Chadha ${ }^{99}$ decided before Justice Scalia joined the Court. Moreover, Scalia's preference for clear rules fits with the Court's increasing reliance in statutory construction on "plain meaning"100 and its sometime aversion to looking

86. See id. at 77.

87. See generally, e.g., Isaac Ehrlich \& Richard A. Posner, An Economic Analysis of Legal Rulemaking, 3 J. LEGAL STUD. 257 (1974); Louis Kaplow, Rules Versus Standards: An Economic Analysis, 42 DUKe L.J. 557 (1992); Duncan Kennedy, Form and Substance in Private Law Adjudication, 89 HARV. L. REv. 1685, 1687-1713 (1976); Kathleen M. Sullivan, The Supreme Court, 1991 Term-Foreword: The Justices of Rules and Standards, 106 HARV. L. REV. 22 (1992).

88. Antonin Scalia, The Rule of Law as a Law of Rules, 56 U. CHI. L. REV. 1175 (1989).

89. Id. at 1179.

90. See id.

91. See id. at 1182 .

92. See id. at 1178 .

93. Id. at 1187.

94. See Popkin, supra note 40 , at $1164-70$.

95. See id. at 1167-69.

96. "What is of paramount importance is that Congress be able to legislate against a background of clear interpretive rules, so that it may know the effect of the language it adopts." Finley v. United States, 490 U.S. 545, 556 (1989).

97. See supra note 41 and accompanying text.

98. See, e.g., Popkin, supra note 40, at 1133-35.

99. 462 U.S. 919 (1983).

100. See, e.g., Union Bank v. Wolas, 112 S. Ct. 527, 531 (1991) ("that Congress may not have foreseen all of the consequences of a statutory enactment is not a sufficient reason for refusing to give effect to its plain meaning"). See generally Richard A. Posner, Legal Formalism, Legal Realism, and the Interpretation of Statutes and the Constitution, 37 CASE W. RES. L. REV. 179 (1986); Patricia M. Wald, 
beyond the text at legislative history. ${ }^{101}$ These, too, are subjects for large debates; ${ }^{102}$ but it is puzzling why it is argued so strongly ${ }^{103}$ that problems with reliance on statutes' legislative history should go to admissibility rather than to weight. $^{104}$ And a strong case has been made that Justice Scalia's approaches to constitutional and statutory interpretation, despite the rhetorical emphasis on a limited judicial role, have the effect of shifting power away from Congress to the Court in constitutional matters and to the executive for the interpretation of statutes. ${ }^{105}$ It seems not out of place to wonder if it is entirely coincidental that the legislative is the only branch of the federal government mostly in liberal hands in recent decades. ${ }^{106}$

No set of attitudes among reasonably sophisticated judges, to be sure, comes unmixed. Those inclined to give considerable weight to states' policies and interests find occasion to uphold strong assertions of federal power. ${ }^{107}$ Those who often call for judicial deference to other branches of the federal government reject nonfrivolous arguments against judicial authority. ${ }^{108}$ And, of course, the tendencies cited as possible explanations for the phenomena described above do not always point in the same direction. Justice O'Connor, who began a 1991 habeas corpus opinion with the statement that "[t]his is a case about federalism, ${ }^{, 109}$ has since written two opinions in effect protesting that in the name of

The Sizzling Sleeper: The Use of Legislative History in Construing Statutes in the 1988-89 Term of the United States Supreme Court, 39 AM. U. L. REV. 277 (1990).

101. See supra note 39. Strong majorities of the current Court have, however, repeatedly rejected Justice Scalia's near-total rejection of the use of legislative history in statutory interpretation. See Conroy v. Aniskoff, 113 S. Ct. 1562, 1567 n.12 (1993); Wisconsin Public Intervenor v. Mortier, 111 S. Ct. 2476, 2484 n.4 (1991).

102. For a somewhat sympathetic exploration of the "plain meaning" approach, see Frederick Schauer, Statutory Construction and the Coordinating Function of Plain Meaning, 1990 SUP. CT. REV. 231.

103. See, e.g., Conroy v. Aniskoff, 113 S. Ct. 1562, 1567, 1572 (1993) (Scalia, J., concurring in judgment) ("The greatest defect of legislative history is its illegitimacy. ... But not the least of the defects of legislative history is its indeterminacy. ... We should not pretend to care about legislative intent (as opposed to the meaning of the law ....")).

104. But see Note, Why Learned Hand Would Never Consult Legislative History Today, 105 HARV. L. REv. 1005 (1992).

105. See Arthur Stock, Note, Justice Scalia's Use of Sources in Statutory and Constitutional Interpretation: How Congress Always Loses, 1990 DUKE L.J. 160.

106. See id. at $192 \mathrm{n} .152$ ("It will be interesting to see whether Justice Scalia modifies his stance in favor of executive power when future executives no longer share his substantive political views.").

107. See, e.g., Hafer v. Melo, 112 S. Ct. 358 (1991) (opinion joined by all eight participating Justices, holding that state officials sued in their individual capacities for official acts are "persons" subject to damage suits under 42 U.S.C. $\$ 1983$, with Eleventh Amendment no bar to such suits in federal court); Howlett v. Rose, 496 U.S. 356 (1990) (unanimous opinion holding that state law sovereign immunity defenses are unavailable against $\$ 1983$ claims in cases in state court).

108. See, e.g., United States Dep't of Commerce v. Montana, 112 S. Ct. 1415, 1424-30 (1992) (unanimously rejecting Department of Justice argument that Congress' choice among alternative House of Representatives apportionment methods was nonjusticiable political question, but upholding selection on merits as within congressional power); Metropolitan Washington Airports Auth. v. Citizens for the Abatement of Aircraft Noise, 111 S. Ct. 2298, 2306 (1991) (finding, without disagreement from opinion dissenting on merits, that citizens living along airport flight paths have standing to bring separation of powers challenge to congressional review board over local airport authority).

109. Coleman v. Thompson, 111 S. Ct. 2546, 2552 (1991). 
federalism the Court was taking, or at least threatening to take, too many liberties with the text of the statute governing federal habeas corpus for state prisoners. ${ }^{110}$

Still, the unstable equilibrium resulting from such tensions yields significant deviations from the triumph of equity in substance and spirit that the three principal articles document in Australia, Delaware, and the United States at large. These deviations to some extent cluster in, without being confined to, the politically sensitive field of federal public law. The justifications that appear to underlie these deviations are weighty and traditionally accorded considerable respect in our jurisprudence. Yet in some of the decisions-such as those making standing doctrine a technical obstacle course to claims by intended beneficiaries of regulation and those refusing, in the name of separation of powers and federalism, to provide full relief for violations of federal rights-the applications seem to reach beyond what the rationales fairly support. They bring to mind the description of an ideologue as one who cares little for the harm done in the name of one's theory.

\section{$\mathrm{V}$ \\ CONCLUSION}

An earlier conservative Justice, who took separation of powers and federalism seriously, showed that they need not become abstractions overriding the real harm of denying full equitable or legal relief. In Bivens, facing the issue of the implication of a legal damages remedy, the second Justice Harlan in his powerful concurrence addressed whether judicial action in a legislative mode was justified in the context before the Court. Exceptionally for him, he concluded that it was. ${ }^{11}$ He further considered the adequacy of other remedies and stressed that "[f]or people in Bivens' shoes, it is damages or nothing."112

Similarly, in a little noticed case in 1960 , Justice Harlan wrote for a majority in upholding the availability of equitable restitution for wages lost when an employer violated federal law by firing employees who had complained of violations of federal wage and hour statutes. "When Congress entrusts to an

110. See Wright v. West, 112 S. Ct. 2482, 2498 (1992) (O'Connor, J., concurring) ("In light of the case law and Congress' position [considering but refusing to enact language establishing a deferential standard], a move away from de novo review of mixed questions of law and fact would be a substantial change in our construction of the authority conferred by the habeas corpus statute."); Keeney v. TamayoReyes, 112 S. Ct. 1715, 1721 (1992) (O'Connor, J., dissenting) ("the balance of state and federal interests regarding whether a federal court will consider a claim raised on habeas cannot be simply lifted and transposed to the different question whether, once the court will consider the claim, it should hold an evidentiary hearing. Moreover, I do not think the Court's decision can be reconciled with 28 U.S.C. $\$$ 2254(d).") (emphasis in original).

111. Bivens v. Six Unknown Named Agents of Fed. Bureau of Narcotics, 403 U.S. 388,407 (1971) (Harlan, J., concurring in judgment) (in resolving "whether compensatory relief is 'necessary' or 'appropriate' to the vindication of the interest asserted ... it seems to me that the range of policy considerations we may take into account is at least as broad as the range of those a legislature would consider with respect to an express statutory authorization of a traditional remedy").

112. Id. at $\mathbf{4 1 0}$. 
equity court the enforcement of prohibitions contained in a regulatory enactment," he wrote, "it must be taken to have acted cognizant of the historic power of equity to provide complete relief in light of the statutory purposes."113 He supported his argument with quotations from early and more recent Supreme Court opinions: In an 1837 decision the Court had said that "there is inherent in the courts of equity a jurisdiction to ... give effect to the policy of the legislature." "114 And a 1946 case under wartime price control regulation had proceeded from the premise that "the comprehensiveness of [federal] equitable jurisdiction is not to be denied or limited in the absence of a clear and valid legislative command." of the equitable tradition. Justice Harlan's history and example show that its greater flourishing in federal public law would be neither innovation nor judicial usurpation.

113. Mitchell v. DeMario Jewelry, Inc., 361 U.S. 288, 291-92 (1960).

114. Clark v. Smith, 38 U.S. (13 Pet.) 195, 203 (1839), quoted in Mitchell, 361 U.S. at 292.

115. Porter v. Warner Holding Co., 328 U.S. 395, 398 (1946), quoted in Mitchell, 361 U.S. at 291. For more extensive discussion of Justice Harlan's position in Mitchell, Bivens, and kindred cases, see Donald H. Zeigler, Justice Harlan and Implied Rights of Action, 36 N.Y.L. SCH. L. REV. 205, 208-13 (1991).

For an example of the continuing debates over the judicial role in assuring full remediation on the modern Court, see Franklin v. Gwinnett County Public Schools, 112 S. Ct. 1028 (1992). Franklin dealt with the availability of damages for sexual harassment and abuse in violation of Title IX of the Education Amendments of 1972, 20 U.S.C. $\$ \S 1681-1688$ (1988). The Court had previously held in Cannon v. University of Chicago, 441 U.S. 677 (1979), that private parties could enforce Title IX through an implied right of action, but it had not dealt specifically with whether money damages were an available remedy. Upholding the damages remedy when the general right of action has already been recognized, Justice White's majority opinion stated as the "general rule" that "absent clear direction to the contrary by Congress, the federal courts have the power to award any appropriate relief in a cognizable cause of action brought pursuant to a federal statute." Franklin, $112 \mathrm{~S}$. Ct. at 1035. Justice Scalia's limited concurrence, joined by Chief Justice Rehnquist and Justice Thomas, questioned the majority's general rule in the context of implied rights of action: "To require, with respect to a right that is not consciously and intentionally created, that any limitation of remedies must be express, is to provide, in effect, that the most questionable of private rights will also be the most expansively remediable." Id. at 1038 (Scalia, J., concurring in the judgment). 
